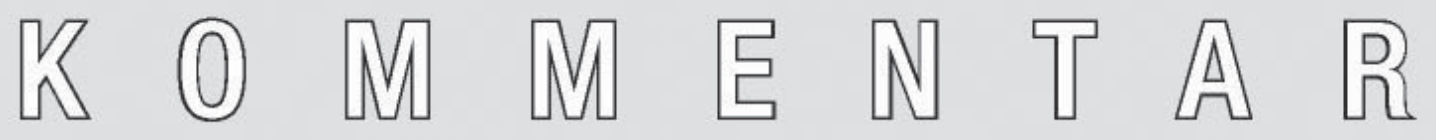

af Annick Prieur

\title{
Vil bibliometrien skade dansk sociologi?
}

Den 5. oktober 2009 smed jeg håndklædet i ringen, efter godt 1 1/2 år som medlem af den sociologiske faggruppe, siden august 2008 som formand. Denne faggruppe har haft i opgave at levere autoritetslister over sociologiske publiceringskanaler. Jeg vil gerne dele nogle tanker, jeg har gjort mig i forbindelse med dette arbejde med det sociologiske fagmiljø.

Det har været et utaknemmeligt arbejde, hvor oplevelsen af meningsløshed lå lige for. Overordnet set handler øvelsen om at lave et mål for forskningsproduktion, der skal anvendes som nøgle til at fordele ressourcer mellem danske universiteter. Denne fordeling bygger i dag ikke på nogle objektive kriterier, men er et rent historisk produkt. Det synes meget fornuftigt at begynde at bruge faste kriterier i denne fordeling, men måske lidt mindre fornuftigt, når den indikator, der skal anvendes, ikke nødvendigvis er en god indikator for forskningskvalitet (mere om dette senere) og endnu mindre fornuftigt, når den kalibreres således, at den i udgangspunktet ikke skal flytte ressourcer hverken mellem hovedområder eller mellem universiteter. Det er altså et kæmpearbejde - til sammen flere årsværk - som nogle hundrede af landets bedst kvalificerede forskere har lagt $i$ at lave en model, der i udgangspunktet skal have mindst mulig betydning.

Det har i den sammenhæng været interessant at følge den skiftende argumentation: På den ene side får vi at vide, at formålet med en bibliometrisk indikator er "at fremme publicering i de mest anerkendte udgivelseskanaler og styrke kvaliteten af dansk forskning" (http://www.fi.dk/forskning/den-bibliometriske-forskningsindikator). Men når det påpeges, at indikatoren ikke er 
videre pålidelig, får vi høre, at det ikke betyder noget, da den alligevel ikke skal bruges til så meget:

Der er fortsat udfordringer. Men modellen kan i sin grundform godt bruges, da det kun er 10 procent af de nye basismidler, som skal fordeles efter indikatoren i 2010. Og fremover vil det faglige grundlag blive bedre, $\mathrm{i}$ takt med at andelen stiger,

siger styregruppens formand Inge Mærkedahl, der samtidig er direktør i Forsknings- og Innovationsstyrelsen. (...) - Som modellen ser ud nu, er det kun ganske lidt, der kan flyttes rundt mellem universiteterne. "Og den skal ikke bruges til at fordele midler mellem de enkelte institutter og forskere", siger Jens Oddershede (begge citater fra http://vtu.dk/nyheder/nyheder-udefra/2009/forskningsindikator-koerer-videre). Det bliver den nu alligevel - $\mathrm{i}$ alle fald til den interne fordeling mellem fakulteterne ved mit universitet (AAU).

Fra begyndelsen til det foreløbige slutpunkt, med en autoritetsliste der blev lagt ud 22. oktober (http://www.fi.dk/forskning/den-bibliometriskeforskningsindikator/autoritetslister-for-tidsskrifter-og-forlag), har processen været dårligt planlagt og styret, og blevet fulgt af protester grundet tidspres, fejlbehæftede lister mv. (Interesserede kan finde en del om nogle af disse problemer på faggruppe 68' site http://faggruppe68.pbworks.com eller på bloggen Forskningsfrihed http://professorvaelde.blogspot.com). Samarbejdet i den sociologiske faggruppe har trods disse betingelser været udmærket. Jeg tror vi har været enige om, at den eneste mening med dette arbejde har været at bidrage til at begrænse skadevirkningerne ved indførelsen af en bibliometrisk indikator, som nok ingen af os mente dybest set ville kunne gavne vort fag, selv om vi i øvrigt kunne have forskellige synspunkter på en del spørgsmål.

Det følgende er kun udtryk for mine egne synspunkter, og de er ret yderliggående: Jeg anerkender hverken målet om, at sociologer skal publicere mere; om at vi skal have højere impact factor; at vi skal publicere mere internationalt, eller at vi skal publicere i tidsskrifter frem for i bøger. Jeg afviser dog ikke, at man skal gøre noget af dette, blot det ikke bliver på bekostning af nogle andre og for mig meget vigtigere mål: At de sociologiske publikationer holder en høj kvalitet og at de er væsentlige, i betydning relevante for vort samfund eller for vor erkendelse.

\section{Hellere udslipskvoter end honorering af kvantitet}

Jeg er gammel nok til at have kendt en anden universitetskultur end den, der nu råder, og selv om den gamle kultur havde mange gode sider, er det ikke svært for mig også at se fremskridt. Det har ved universiteterne været nødvendigt at få præciseret, at forskning ikke kun er en ret vi VIP'ere har, men også en pligt, og at den pligt kun indfris, hvis man faktisk publicerer. Det betyder imidlertid ikke, at jo mere man publicerer, jo bedre er det. 
Den bibliometriske indikator er tænkt at måle kvantitet og kvalitet samtidigt. Det kvantitative behøver ingen forklaring. Det kvalitative skal sikres for det første ved, at alt som måles, skal have gået igennem fagfællebedømmelse, og for det andet ved at de i fagmiljøet mest anerkendte publiceringskanaler også skal vægte tungest. Min bekymring er, om ikke indikatoren alligevel vil fremme det kvantitative på bekostning af det kvalitative.

$\mathrm{Nu}$ indfører man et system, hvor den strategisk handlende vil dele sit stof op, således at man kan få flest mulig artikler ud af det. Med lidt skiftende vinklinger og opdelinger kan man jo få mange blot lidt forskellige artikler ud af et enkelt forskningsarbejde, men uden at de efterfølgende artikler giver nogen dybere indsigt, end hvad den første gav.

I mine øjne ville sociologifaget faktisk være bedre tjent med udslipskvoter end med honorering for omfattende publicering. Hvis hver enkelt havde et begrænset antal sider årligt at gøre godt med, ville vi holde os til at sige noget væsentligt, og vi ville til og med have mulighed for at læse hvad vore kolleger skrev. Nu halser man videre og publicerer uden hverken at læse ordentligt eller tænke ordentligt. Flere og flere af os bliver stadig dygtigere til fast reading, hvor vi skimmer artikler således, at vi lige kan hægte nogle flere referencer på i vore egne artikler, men uden at gå ind i dybere diskussioner.

På længere sigt er jeg bange for, at vi undergraver vor egen faglighed.

\section{Impact og nysprog}

Et tidsskrifts impact factor er et af de forhold, der er blevet bragt i spil på mange fagområder ved rangering af tidsskrifter, dog har vi heldigvis tillagt det mindre betydning i sociologi (blandt andet fordi data foreløbig ikke er gode nok, så det er måske blot en udsættelse). Begrebet impact factor er for mig som hentet fra Orwell. Det beregnes ud fra, hvor mange gange et tidsskrifts artikler gennemsnitligt citeres i andre tidsskriftsartikler i de første to år efter publicering. Men har min forskning om det samfund, der omgiver mig, virkelig impact, hvis nogle kolleger i fjerne lande henviser til nogle artikler fra det samme tidsskrift i nogle tidsskrifter, kun vi og nogle andre sociologer læser? Er det virkelig kun impact på andre forskere, som skal gælde som netop impact? Hvad med den impact sociologien kan have på det omgivende samfund - hvad enten det er gennem nye sociale ordninger eller gennem nye begreber og forståelsesmåder?

En citations-impact er selvsagt meget nemmere at måle, end en samfundsmæssig impact vil være, men det gør den ikke til et godt mål - i alle fald ikke for et fag som sociologi. Her spiller også tidsfaktoren ind, da to år er en meningsløst kort tidshorisont for en sociologisk indsigt.

\section{Dansk malinchismo}

På mexicansk-spansk findes udtrykket malinchismo, der viser til den tilfangetagne høvdingedatter Malinche, der takket være sit sprogtalent blev den 
spanske erobrer Hernán Cortés' tolk, rådgiver og elskerinde, og hun fik også et barn med ham. Hun fik senere den tvivlsomme rolle at inkarnere det at begære det udenlandske på bekostning af det nationale.

Mit spørgsmål er, om ikke en form for malinchismo er ved at brede sig i dansk akademisk kultur: Alt udenlandsk (læs engelsksproget) er "fint", mens det danske er andenrangs. Jeg anerkender målet om, at internationalisere dansk forskning ved at fremme kommunikation med forskere i andre lande. Det vil fremme en bedre håndtering af både metodiske og teoretiske redskaber i sociologien, og det vil fremme, at man holder sig opdateret med den faglige udvikling. Jeg ved udmærket godt, at de internationale artikler, jeg har kæmpet med at skrive, ved at arbejde mig gennem den internationale litteratur, ved at skære ræsonnementet ind til benet, ved at forholde mig til mavesure refereeudtalelser osv. - disse artikler er også blevet meget bedre end de arbejdspapirer, jeg i stedet kunne have udgivet i en lokal skriftserie. Så det er klart, vi sociologer her i Danmark skal være med og publicere internationalt. Men det bør ikke være det eneste vi laver.

Den drejning af faglig orientering, som niveaudelingen medfører, hvor nu udelukkende engelsksprogede (og et par fransk- og tysksprogede) tidsskrifter rangeres på højeste niveau i sociologi, leder os mod at publicere mere og mere på engelsk i tidsskrifter, der kun læses af (et fåtal) andre forskere, og som de kun læser for at bruge dette i deres egen forskning. Sociologifaget har i mine øjne sin primære mission i en kritisk dialog med det samfund, det omhandler - en dialog med dette samfunds offentlighed i en bred forstand. Udviklingen nu fremmer en samfundsmæssigt mindre væsentlig og dårligere kommunikeret sociologi.

Det er ikke alle spørgsmål danske samfundsforskere arbejder med, som har den samme internationale interesse. Jeg frygter, at det vil være til stor skade for disse forskningsområder, hvis autoritetslisterne fører til en alt for stor orientering af sociologien væk fra danske samfundsforhold. Derfor mener jeg, det er vigtigt, at der fremdeles skal findes publiceringskanaler på højt niveau for denne forskning. Dette vil give en tilskyndelse til at publicere på dansk og også en reel konkurrence om at publicere i de bedste tidsskrifter.

I faggruppen var vi uenige om, hvorvidt tidsskriftet Dansk Sociologi kunne siges at leve op til kriterierne for at være et niveau 2-tidsskrift, men et flertal i gruppen valgte at indstille det som det. Dette blev ikke godkendt af Fagligt Udvalg (det overordnede udvalg, der er nedsat til at styre processen for alle faggrupper), der bad om en begrundelse for vor indstilling. Jeg skrev så følgende:

Dansk Sociologi er i dag det mest læste og diskuterede tidsskrift blandt danske sociologer. Der er ingen tvivl om, at redaktionen i de senere år har arbejdet meget målrettet mod at professionalisere bedømmelsesarbejdet og internationalisere tidsskriftet, og tilstrømningen af artikler 
har været i kraftig vækst i de senere år, således at der nu allerede er en betragtelig konkurrence om at publicere i dette tidsskrift. Der synes også at være en øget tilstrømning af artikler fra andre end danskbaserede forskere.

Stillet overfor denne positive udvikling kunne vi vælge at sige, at vi ikke synes tidsskriftet helt lever op til niveau 2-standarden endnu, og så formentligt blive vidner til, at de bedste forfattere søger andetsteds hen med deres artikler, og tidsskriftets kvalitetsniveau og anseelse så falder. Eller vi kunne vælge at sige, at vi tildeler niveau 2 nu med forventning om, at tidsskriftet så også kommer til at leve op til kravene fremover: Denne rangering vil formentligt sikre en så god tilstrømning af artikler, at kvalitetskravet indfries. Allerede rygtet om en forventet niveau 2-placering siges at have haft en sådan effekt. En tilsvarende udvikling har man også tidligere kunnet se i forbindelse med, at det nordiskbaserede Acta Sociologica fik niveau 2-status i Norge. Over for nordiske tidsskrifter må man jo erkende, at autoritetslisterne ikke bare genspejler virkelighedens kvalitetsskel, men også medvirker til at skabe dem.

I erkendelse af dette ansvar landede faggruppen altså på at tildele niveau 2 nu. Men hvis de forventninger beslutningen hviler på ikke indfries, vil Dansk Sociologi selvsagt måtte nedklassificeres ved en senere beslutningsrunde.

Denne begrundelse blev ikke anset som god nok, og tidsskriftet blev følgelig nedgraderet. Derfor er der pt. ikke en eneste dansksproget publiceringskanal på højt niveau for sociologi.

\section{Hvem står for den faglige autoritet?}

Afslaget gjorde det tydeligt for mig, at faggruppen alligevel ikke sad med den faglige autoritet bag ved det bibliometriske maskineri. Det førte så til, at jeg valgte at trække mig fra faggruppen, med følgende begrundelse:

Jeg har levet i den vildfarelse, at de syv sociologer i faggruppe 21 var udpeget som repræsentanter for centrale sociologiske fagmiljøer for at udøve et fagligt skøn ingen andre end netop repræsentanter for sociologifaget kunne udøve. Når jeg nu erfarer, at der alligevel ikke bliver lyttet til vore vurderinger, og Fagligt udvalg underkender vor niveauindstilling, kan jeg ikke længere se nogen grund til at blive siddende som faggruppeformand. Dette handler ikke om det enkelte tidsskrift, som vi her er uenige om, men om princippet: Om hvem, der skal have det sidste ord. Når det på denne måde bliver åbenlyst, at det ikke er fagmiljøet selv, der har den højeste faglige autoritet, anser jeg arbejdet $\mathrm{i}$ en faggruppe som meningsløst. 
De andre faggruppemedlemmer var enige i det principielt forkerte i at beslutningskompetencen ikke skulle ligge hos os, men har valgt at blive siddende.

\section{Bogpubliceringer}

Der er en bevægelse på vej mod mere artikelskrivning og mindre vægt på bøger blandt sociologer. Kikker man på fagets historie, springer det alligevel i øjnene, at det tit er bøger, der har bidraget mest til udvikling af faget. Det er min erfaring, når jeg taler med andre sociologer, at spørger man til, hvad de har læst, der virkelig har påvirket dem som sociologer, vil de fleste trække frem flere bøger end artikler. Det er også i stor grad bøger vi refererer til på vore litteraturlister. Det er min overbevisning, at der ikke kun er historiske grunde til dette, men at det også hænger sammen med fagets natur: De dybe ræsonnementer om samfundet kræver plads til udfoldelse af et argument, plads til dokumentation og til nuancer.

Spørgsmålet om det skal være muligt at få bogpubliceringer niveauinddelt, er blevet udskudt af Fagligt Udvalg, da problemerne på nuværende tidspunkt var uoverstigelige. På den ene side vil det være forkert, at fag, hvor bogpublicering på dansk faktisk er det mest prestigegivende (det gælder særligt inden for nogle humanistiske fag), ikke skal kunne have sådanne publikationer på højeste niveau. På den anden side vil en autoritetsliste med nogle enkelte danske forlag på niveau 2 indebære en betydelig konkurrencevridning af forlagsverdenen. Videre er det jo ikke således, at et forlag (dansk eller internationalt), der holder et højt niveau inden for et fagområde, nødvendigvis også gør det inden for alle andre fagområder. Og der er desuden det problem, at forlag drives af kommercielle og ikke af videnskabelige interesser, hvorfor det er svært at forestille sig, at det udelukkende vil være hensynet til videnskabelig kvalitet, der vil styre et forlags beslutninger om udgivelser.

Af disse grunde ville det i mine øjne have været mest hensigtsmæssigt at helt undlade niveauinddeling af forlag. Vi skal nok sagtens forsøge at publicere ved de gode forlag alligevel. Nu er rangeringen blot udskudt i nogle år med forhåbninger om, at der i løbet af den tid kan være blevet etableret fagligt afgrænsede bogserier med en høj videnskabelig standard, der så kan aspirere til niveau 2, i stedet for at hele forlag kommer på dette niveau. Lad os så håbe, at der kan etableres mindst én sådan serie for sociologi på dansk. Vor mulighed for på samme vis at påvirke internationale forlag er minimal, og det er højst åbent, om det vil være muligt at etablere enighed med andre faggrupper om rangering af de internationale forlag.

\section{Forsvar mod ligegyldighed}

Betydningen af den bibliometriske indikator for ressourcefordeling mellem universiteterne har vi ikke selv nogen kontrol over. Men det er alligevel sociologerne i Danmark, altså os selv, der langt hen ad vejen bestemmer, hvilken betydning denne indikator skal få for vort fag. Det er os selv, der bestemmer, 
om vi vil lade vore egne anerkendelseskriterier være de samme, som de som ligger nedfældet i denne indikator. Det er os selv, der bestemmer, hvad kriterierne for en artikels kvalitet skal være, og hvor godt et givet tidsskrift skal være, når vi skriver eller vurderer artikler for dette tidsskrift.

Enhver, der ønsker en forskningskarriere inden for sociologi, bliver nødt til at publicere internationalt. Der ligger tit et kæmpearbejde bag disse publikationer, tit holder de også en høj faglig kvalitet, og dette skal selvsagt anerkendes. Men det er alligevel den enkelte, der beslutter, om denne type publikationer skal være de eneste man skriver, og det er os sociologer som sammen beslutter, om vi også skal anerkende andre udtryk for faglig kvalitet. Det er som bedømmere af afhandlinger, af forsknings- eller stillingsansøgninger, at vi selv også tager stilling til, hvilken anerkendelse man skal have for andre egenskaber end en høj score på den bibliometriske indikator. Disse andre egenskaber kan jo være at have behandlet væsentlige spørgsmål for det danske samfund eller at have bidraget til den sociologiske refleksion i den nordiske offentlighed, mv.

Her er det ikke svært at forudse en tilspidset generationskonflikt. De unge er nødt til at tilpasse sig de nye kriterier for deres karrierers skyld, og mange unge kommer hurtigt til at score højere på den bibliometriske indikator end den ældre generation, der sidder på positionerne og magten til at bedømme de unges præstationer og kvalifikationer, når de afleverer afhandlinger, ansøger om forskningsmidler eller stillinger. Bliver vi i den ældre generation så museumsvogtere i den unge generations øjne, hvis vi forsøger at holde på bredere anerkendelseskriterier?

Jeg håber det ikke, da jeg mener, vi har en fælles interesse som sociologer i at forsvare faget mod en omsiggribende "ligegyldighedsgørelse".

Annick Prieur

E-mail: ap@socsci.aau.dk 